\title{
DEFINICIJA KOLEKTIVNOG VIŠKA RADNIKA U EUROPSKOM I HRVATSKOM RADNOM ZAKONODAVSTVU
}

UDK: 349.2

Primljeno: 15. 10. 2016.

Pregledni rad

\begin{abstract}
U ovom radu razmatra se kada dolazi do primjene zaštite u slučaju kolektivnog otkazivanja po europskom i hrvatskom radnom pravu, s posebnim naglaskom na pitanje načina izračuna viška radnika. Analizira se pitanje je li poslodavac prilikom davanja otkaza većem broju radnika dužan voditi računa o svim danim otkazima na razini cijelog društva ili u izračun dolaze samo oni otkazi dani u okviru pojedine poslovnice ili pogona poslodavca. U prvom dijelu rada se analizira europsko zakonodavstvo i praksa Suda EU, s posebnim osvrtom na predmet Woolworths. U drugom dijelu autor iznosi relevantne odredbe hrvatskog Zakona o radu, analizira određena otvorena pitanja usklađenosti, dužnosti i odgovornosti zakonodavca i sudova u slučaju neprimjene ili nepravilne primjene direktive, te zaštite radnika u slučaju propusta poslodavaca.
\end{abstract}

Ključne riječi: kolektivno otkazivanje, pogon, višak radnika

\section{UVOD}

Temeljno je obilježje radnoga zakonodavstva pronalazak pravog balansa između zaštite radničkih prava i obaveza poslodavaca, što posebno dolazi do izražaja u području otkazivanja. S jedne strane, potrebno je osigurati adekvatnu zaštitu radnicima od samovoljnog i diskrecijskog odlučivanja poslodavca u slučaju otkazivanja, dok je s druge strane nužno omogućiti poslodavcima da brzo i efikasno donose poslovne odluke koje se tiču upravljanja ljudskim resursima i optimizacije troškova. Ukoliko poslodavac otkazuje ugovore o radu većem broju radnika unutar određenog razdoblja, u primjenu dolazi kolektivna zaštita koja nameće dodatne obveze i troškove poslodavcima. Stoga se može zaključiti da je pitanje kolektivnog otkazivanja jedno od najosjetljivijih pitanja radnog zakonodavstva, te da nije uvijek jednostavno, niti zakonodavcu niti sudovima, pronaći pravi omjer zaštite jedne i druge strane. 


\section{PRIMJENA ODREDBI O KOLEKTIVNOM VIŠKU RADNIKA U EUROPSKOM RADNOM ZAKONODAVSTVU}

\subsection{Značenje i ciljevi kolektivne zaštite u europskom radnom zakonodavstvu}

Temeljni europski pravni propis koji regulira pitanje kolektivnog viška radnika jest Direktiva Vijeća 98/59 od 20. srpnja 1998. o usklađivanju zakonodavstava država članica u odnosu na kolektivno otkazivanje ${ }^{1}$ (dalje u tekstu kao: Direktiva 98/59), koja je zamijenila direktivu donesenu još 1975 . godine ${ }^{2}$ kojom je bilo uređeno isto područje.

Formalni temelj za donošenje Direktive 98/59 jest članak 115. Ugovora o funkcioniranju Europske unije (dalje u tekstu kao: UFEU), ${ }^{3}$ temeljem kojeg je dana ovlast Vijeću Europske unije da donosi direktive za usklađivanje onih zakona ili drugih propisa država članica koji neposredno utječu na uspostavu ili funkcioniranje unutarnjeg tržišta. Međutim, neovisno na formalno pozivanje na pravni temelj povezan s funkcioniranjem unutarnjeg tržišta, nesporno jest da je Direktiva 98/59 dio radnog i socijalnog zakonodavstva Europske unije, te da je bitan dio europskog stupa socijalnih prava ${ }^{4}$. Prema članku 151. UFEU-a, područje socijalne politike spada u područje podijeljene nadležnosti između Europske unije i država članica, prema kojem ,....Europska unija i države članice imaju za cilj promicanje zapošljavanja, poboljšanje životnih i radnih uvjeta, kako bi se na putu napretka omogućilo njihovo usklađivanje“. Drugim riječima, u području socijalne politike institucije Europske unije imaju ovlast usvajati određene ,minimalne uvjete" koji će se primjenjivati u državama članicama, ${ }^{5}$ dok je državama članicama ostavljena mogućnost daljnjeg uređenja predmetnog pitanja. ${ }^{6}$

Imajući prethodno navedeno u vidu, u Preambuli Direktive 98/59 se navodi svrha donošenja tog propisa, te se u tom smislu navodi da je važno radnicima pružiti veću zaštitu u slučaju kolektivnog otkazivanja, uzimajući u obzir potrebu za

1 SL L 225, 12. VIII. 1998., str. 16-21; pročišćeni tekst dostupan na http://eur-lex.europa.eu/ legal-content/HR/TXT/HTML/?uri=CELEX:01998L0059-20151009\&qid=1468669417291\&from=HR (pregledano 15. VII. 2016. godine).

2 Direktiva Vijeća 75/129/EEZ od 17. veljače 1975. o usklađivanju zakonodavstava država članica u odnosu na kolektivno otkazivanje, SL L 48, 22. II. 1975.

3 Pročišćena inačica dostupna na http://www.mvep.hr/custompages/static/hrv/files/ pregovori/111221-lisabonski-prociscena.pdf (pregledano 20. VII. 2016. godine).

4 Vidi više u Komunikaciji Komisije Europskom Parlamentu, Vijeću, Europskom gospodarskom i socijalnom odboru i Odboru regija, o Pokretanju javne rasprave o europskom stupu socijalnih prava, dostupno na http://ec.europa.eu/transparency/regdoc/rep/1/2016/HR/1-2016-127-HR-F1-1.PDF (pregledano 20. VII. 2016. godine).

Vidi članak 153. stavak 2. točka 2. UFEU.

6 Predmet United Kingdom of Great Britain and Northern Ireland v Council of the European Union, C-84/94 (1997) ECR I-03519, paragraf 17. 
uravnoteženim ekonomskim i socijalnim razvojem unutar Europske unije. ${ }^{7}$ Nadalje, navodi se da usprkos usklađenosti, još uvijek postoje razlike između odredbi koje su na snazi u državama članicama u pogledu praktičnih rješenja i postupaka pri kolektivnom otkazivanju, te da takve mjere mogu imati izravan učinak na funkcioniranje unutarnjeg tržišta. Znači, prilikom kolektivnog otkazivanja potrebno je s jedne strane zaštititi radnike, ali s druge strane i propisati usporedive obveze poslodavaca te time osigurati pravilno funkcioniranje unutarnjeg tržišta. Stoga je Sud Europske unije ${ }^{8}$ (dalje u tekstu kao: Sud EU) imao ulogu dodatno pojasniti i analizirati odnos ova dva naizgled suprotstavljena cilja, te odlučiti kojemu će ipak dati prednost i na kojemu će temeljiti svoja tumačenja Direktive 98/59.

\subsection{Definicija kolektivnog otkazivanja prema Direktivi Vijeća 98/59}

U smislu članka 1. Direktive 98/59 kolektivno otkazivanje znači otkazivanje što ga provodi poslodavac iz jednog ili više razloga koji se ne odnose na osobu radnika kada, prema izboru države članice, višak radnika iznosi:

i. u razdoblju od 30 dana:

- $\quad$ najmanje 10 u pogonima koji inače zapošljavaju više od 20, a manje od 100 radnika,

- najmanje $10 \%$ od broja radnika u pogonima koji inače zapošljavaju najmanje 100, ali manje od 300 radnika,

- najmanje 30 u pogonima koji inače zapošljavaju 300 ili više radnika,

ii. ili, u razdoblju od 90 dana, najmanje 20 , bez obzira na broj inače zaposlenih radnika u određenom pogonu.

Radi preglednosti teksta, za opciju navedenu pod (i) dalje u tekstu će se koristiti termin „Opcija 1“, a za opciju navedenu pod (ii), „Opcija 2“. Većina država članica Europske unije je u svoje zakonodavstvo implementirala Opciju 1, dok je Republika Hrvatska (dalje u tekstu kao: Hrvatska) zajedno s Velikom Britanijom, Švedskom, Luksemburgom, Nizozemskom i Portugalom ${ }^{9}$ usvojila Opciju 2.

Osim navedenog objektivnog kriterija o kojem je potrebno voditi računa prilikom kolektivnog otkazivanja, Direktiva 98/59 navodi i subjektivni kriterij propisujući

7 Vidi Preambulu Direktive 98/59, paragraf 2.

8 Sud Europske unije (Court of Justice of the European Union) sastoji se od tri tijela: (i) Sud (Court of Justice), koji rješava zahtjeve za prethodne odluke što ih podnose nacionalni sudovi, određene postupke za poništenje i žalbene postupke, (ii) Opći sud (General Court), koji donosi odluke u postupcima za poništenje što su ih pokrenuli pojedinci, društva i, u nekim slučajevima, vlade država članica EU, te (iii) Službenički sud (Civil Service Tribunal), koji sudi u sporovima između Europske unije i njezina osoblja. Za potrebe ovog rada, koristi se opći naziv Sud Europske unije. Vidi više na https://europa.eu/ european-union/about-eu/institutions-bodies/court-justice_hr\#nadležnosti-suda-eu-a (pregledano 20. VII. 2016. godine).

9 Vidi članak Reade QC, David: „International Corporate Rescue: Woolworths and the ECJ case Review", dostupno na http://www.littletonchambers.com/international-corporate-rescue-woolworths-andthe-ecj-case-review-896/ (pregledano 25. VII. 2016. godine). 
razloge koji su relevantni za kolektivno otkazivanje. ${ }^{10} \mathrm{U}$ tom smislu, propisano je da se za izračun broja viška radnika, prestanak radnog odnosa na inicijativu poslodavca iz jednog ili više razloga koji se ne odnose na osobu radnika, izjednačuje s kolektivnim otkazivanjem, pod uvjetom da postoji najmanje pet takvih otkaza. ${ }^{11}$

Direktivom 98/59 dalje su razrađeni postupci obavješćivanja i savjetovanja, te sam postupak kolektivnog otkazivanja. Posebno je važno istaknuti da prema članku 5. Direktive $98 / 59$, država članica može primijeniti ili donijeti zakon ili drugi propis povoljniji za radnike ili omogućiti primjenu kolektivnih ugovora koji su povoljniji za radnike.

\subsection{Značenje pojma ,pogon“ (eng. ,establishment")}

Detaljnim pregledom članka 1 . Direktive $98 / 59$, može se zaključiti da je za određivanje načina izračuna viška radnika ključno odrediti značenje i tumačenje pojma „pogon“" (engleski pojam: „establishment"). Naime, ovisno o definiciji pojma ,pogon" dolazimo do odgovora je li za izračun viška radnika kod kolektivnog otkazivanja relevantan broj otkaza u jednom pogonu (kao dijelu poduzeća) ili se uzima u obzir broj svih otkaza kod određenog poslodavca (u svim pogonima). S obzirom da pojam ,pogon“ nije definiran Direktivom 98/59 niti odredbama UFEU, njegovo tumačenje i definiciju odredio je Sud EU u svojoj praksi.

Kod Opcije 2 termin „pogon“ se ne navodi izravno kao kod Opcije 1, već samo u kontekstu rečenice „,bez obzira na broj inače zaposlenih radnika u određenom pogonu". Stoga je ostavljen prostor različitom tumačenju navedene odredbe. Drugim riječima, zadatak sudske prakse bio je utvrditi je li namjera donositelja Direktive 98/59 zaista bila da se i kod Opcije 2 ograniči definicija kolektivnog viška radnika na pojam pogona ili se u obzir uzimaju svi otkazi kod poslodavca.

\subsubsection{Definiranje pojma ,pogon" u ranijoj praksi Suda}

Sud EU je predmetni pojam ,pogon“ prvi put definirao 1995. godine u predmetu Rockfon. ${ }^{12}$ Tada je Sud EU ponovio svoje stajalište prethodno izneseno u predmetu Botzen i $d r{ }^{13}$ iz 1985. godine, navodeći da je radni odnos u bitnome obilježen vezom koja postoji između radnika i dijela poduzeća u koji je on raspoređen za obavljanje svoje zadaće. Imajući navedeno u vidu, Sud EU je u točki 32. predmeta Rockfon odlučio da pojam ,pogon“ iz članka 1. Direktive 98/59 treba tumačiti na način da se, ovisno o okolnostima, odnosi na ,jedinicu u koju su radnici na koje se

10 Bernard, Catherine: „EU Employment Law“, fourth edition, Oxford University Press, 2012, stranica 631

11 Vidi članak 1. stavak 2. Direktive 98/59.

12 Predmet Rockfon A/S v Specialarbejderforbundet i Danmark, C-449/93 (1995.) ECR I-04291, presuda od dana 7. prosinca 1995. godine.

13 Predmet Arie Botzen and others v Rotterdamsche Droogdok Maatschappij BV., C-186/83 (1985.) ECR I-00519, presuda od 7. veljače 1985. godine, paragraf 15. 
otkazivanje odnosi raspoređeni za obavljanje svojih zadataka“. Za definiciju pojma „pogon" nije bitna činjenica raspolaže li predmetna jedinica upravom koja može na samostalan način provesti kolektivna otkazivanja.

Međutim, za jasniju definiciju bilo je potrebno čekati daljnjih 12 godina. Sud EU je u predmetu Athinaïki Chartopoiïa ${ }^{14}$ iz 2007. godine dao dodatna pojašnjenja pojma ,pogon“", navodeći da u svrhe primjene Direktive 98/59 „pogon“ može u okviru poduzeća biti zasebno tijelo koje:

i. ima određenu trajnost i stabilnost;

ii. kojemu je povjereno izvršavanje jedne ili više određenih zadaća;

iii. koje raspolaže cjelinom radnika i tehničkih sredstava te određenom organizacijskom strukturom koja omogućuje ispunjenje tih zadaća: ${ }^{15}$

iv. koje ne mora nužno imati pravnu, gospodarsku, upravnu ili tehnološku autonomiju da bi ga se smatralo pogonom. ${ }^{16}$

Iz predmeta Athinaïki Chartopoïa jasno proizlazi da je Sud EU uporabom izraza „zasebno tijelo" $\mathrm{i}$, , u okviru poduzeća“" pojasnio da su pojmovi ,poduzeće“ i , ,pogon“ različiti te da pogon uobičajeno čini dio poduzeća. To ipak ne isključuje mogućnost podudaranja pogona i poduzeća u slučaju kad poduzeće nema više zasebnih jedinica.

\subsubsection{Definiranje pojma „pogon“ u recentnoj praksi Suda EU}

Iz recentne sudske prakse Suda EU potrebno je izdvojiti tri ključne presude donesene u travnju i svibnju 2015. godine. U predmetima Woolworths, ${ }^{17}$ Lyttle ${ }^{18} \mathrm{i}$ Cañas, ${ }^{19}$ nacionalni sudovi iz Engleske i Walesa (Ujedinjena Kraljevina), Sjeverne Irske (Ujedinjena Kraljevina), i Spanjolske uputili su zahtjeve za prethodnu odluku Sudu EU o suštinski istom pitanju, a koje se odnosi na određivanje točnog opsega pojma ,pogon" navedenog u Opciji 2 Direktive 98/59 za potrebe određivanja je li riječ o kolektivnom otkazivanju.

U nastavku se daje pregled pravne i činjenične pozadine u predmetu Woolworths, te osvrt na zaključke iz presude. Naime, radi se o primjeru koji najjasnije pokazuje opseg značenja pravilnog definiranja pojma ,pogon“ i posljedice koje različita tumačenja mogu imati na razinu zaštite radničkih prava i obveza poslodavaca. Sud EU je gotovo na identičan način ponovio stavove iz predmeta Woolworths i u

14 Predmet Athinaïki Chartopoï̈a AE protiv L. Panagiotidis i dr, C-270/05 (2007.) ECR I-01499, presuda od 15. veljače 2007. godine.

15 Predmet Athinaïki Chartopoïa, paragraf 27.

16 Predmet Athinaïki Chartopoïa, paragraf 28.

17 Predmet Union of Shop, Distributive and Allied Workers (USDAW), B. Wilson protiv WW Realisation $1 \mathrm{Ltd}$, u stečaju, Ethel Austin Ltd $i$ Secretary of State for Business, Innovation and Skills, C-80/14, presuda od 30. travnja 2015. godine.

18 Predmet Valerie Lyttle, Sarah Louise Halliday, Clara Lyttle, Tanya McGerty protiv Bluebird UK Bidco 2 Ltd, C-182/13, presuda od 13. svibnja 2015. godine.

19 Predmet Andrés Rabal Cañas protiv Nexea Gestión Documental SA, Fondo de Garantía Salarial, C-392/13, presuda od 13. svibnja 2015. godine. 
predmetu Lyttle ${ }^{20}$ dok je naglasak u predmetu $C a \tilde{n} a s^{21}$ stavljen i na druga postavljena pitanja, koja nisu predmet analize u ovom radu.

\subsubsection{Predmet Woolworths}

\section{Pravni okvir i glavni postupak}

Financijski problemi i u konačnici stečaj nacionalnih društava za maloprodaju WW Realisation 1 Limited i društva Ethel Austin Limited koja su poslovala pod nazivom „Woolworths“ odnosno „Ethel Austin“ prouzročila su davanje otkaza tisućama radnika u Ujedinjenom Kraljevstvu. Sindikalna organizacija USDAW podnijela je tužbe pred Liverpool i London Central Employment Tribunals (središnji sudovi za radno pravo u Liverpoolu i Londonu) protiv društava Woolworths i Ethel Austin u ime nekoliko tisuća članova USDAW-a, koji su bili zaposleni u tim društvima, te koji su dobili poslovno uvjetovani otkaz jer su bili višak.

Relevantni zakonodavni okvir Ujedinjenog Kraljevstva ${ }^{22}$ za predmet Woolworths propisuje da kada poslodavac predlaže otpuštanje kao viška 20 ili više radnika $u$ jednom pogonu u razdoblju od 90 dana ili manje, poslodavac se mora o otkazima savjetovati s mjerodavnim predstavnicima radnika. U suprotnome, sud za radne odnose može naložiti poslodavcu da isplati zaštitnu naknadu otpuštenim radnicima, zato što nije poštovan postupak savjetovanja koji prethodi planu zbrinjavanja što predviđa zakon. U tom kontekstu, postupku se pridružio i Secretary of State (Državni tajnik) kao stranka, s obzirom da je Secretary of State potencijalno odgovoran za isplatu zaštitnih naknada u slučaju insolventnosti poslodavca.

Odlukama navedenih prvostupanjskih sudova dodijeljene su zaštitne naknade određenom broju radnika koje su otpustili Woolworths i Ethel Austin. Međutim, za oko 4500 radnika ta je zaštitna naknada odbijena, zato što su radili u trgovinama s manje od 20 radnika, te je prvostupanjski sud zauzeo stajalište da se svaka trgovina mora smatrati zasebnim pogonom.

U žalbenom postupku Employment Appeal Tribunal (Žalbeni sud za radno pravo) je, između ostalog, ${ }^{23}$ zaključio da je potrebno zanemariti izraz,$u$ jednom pogonu" kako bi se osiguralo pravilno tumačenje odredbe nacionalnog prava kojim je implementirana Direktiva 98/59. ${ }^{24}$ Sud je obrazložio takav stav pozivajući se na doktrinu o indirektnom (interpretativnom) učinku direktiva, odnosno obvezu

20 Predmet Lyttle, paragrafi 26-34, 53.

21 Predmet Cañas, paragraf 41-49.

22 Poglavlje II. Dio IV. Trade Union and Labour Relations (Consolidation) Act 1992. (Konsolidirani zakon o sindikatima i radnim odnosima).

23 Employment Appeal Tribunal također je zaključio da se radnici koji su dobili otkaz mogu izravno pozivati na direktivu te je odredio da je Secretary of State odgovoran za isplatu zaštitnih naknada svim radnicima.

24 Članak 188. stavka 1. Trade Union and Labour Relations (Consolidation) Act 1992. 
nacionalnog suca da tumači svoje nacionalno pravo u svjetlu teksta i svrhe direktive. ${ }^{25}$ Iz navedenog zaključka žalbenog suda (koji je suprotan zaključku prvostupanjskog suda) proizlazi da se obveza prethodnog savjetovanja primjenjuje onda kada poslodavac namjerava otpustiti 20 i više radnika iz poslovno uvjetovanih razloga tijekom razdoblja od 90 dana ili manje, neovisno o tome u kojim pogonima stvarno rade. Stav Employment Appeal Tribunala imao je velik odjek u britanskoj javnosti, s obzirom da je time opseg primjene zaštite pri kolektivnom otkazivanju značajno proširen. Poslodavci iz Ujedinjenog Kraljevstva ostali su zatečeni tumačenjem zakonodavnog okvira koji podrazumijeva da se izračun broja od 20 radnika može vrlo brzo dosegnuti.

Secretary of Stateu bilo je dopušteno podnijeti žalbu protiv odluke Employment Appeal Tribunal pred Court of Appeal (England \& Wales) Civil Division (Žalbeni sud (Engleske i Walesa) građanski odjel). Budući da je Court of Appeal imao sumnje u pogledu ispravnog tumačenja Direktive 98/59, taj je sud odlučio prekinuti postupak, te uputiti sljedeća najvažnija pitanja Sudu EU radi donošenja prethodne odluke; ${ }^{26}$

odnosi li se izraz „,najmanje 20“ naveden u Opciji 2 Direktive 98/59 na broj otkaza u svim poslodavčevim pogonima u kojima su provedeni otkazi u razdoblju od 90 dana ili se odnosi na broj otkaza u svakom pojedinačnom pogonu;

ako se Opcija 2 odnosi na broj otkaza u svakom pojedinačnom pogonu, kako treba tumačiti pojam ,pogon'.

25 Detaljnije o doktrini indirektnog (interpretativnog) učinka direktiva vidjeti u poglavlju Dužnost i odgovornost države po pravu Europske unije ovoga rada.

26 Potpun tekst upućenih pitanja (Predmet Woolworths, paragraf 42):

„1. a) Odnosi li se izraz ,najmanje 20“ u članku 1. stavku 1. točki (a) podstavku ii. [Direktive 98/59] na broj otkaza u svim poslodavčevim pogonima u kojima su provedeni otkazi u razdoblju od 90 dana ili se odnosi na broj otkaza u svakom pojedinačnom pogonu?

b) Ako se članak 1. stavak 1. točka (a) podstavak ii. odnosi na broj otkaza u svakom pojedinačnom pogonu, kako treba tumačiti pojam ,pogon“? Osobito, treba li pojam „pogon“ tumačiti tako da znači ukupnu predmetnu djelatnost maloprodaje, koja se smatra jednom poslovnom jedinicom, ili dio te djelatnosti u kojem se namjerava provesti kolektivno otkazivanje, a ne da znači jedinicu u koju je zaposlenik raspoređen za obavljanje zadataka, kao što je pojedinačna trgovina?

2. Može li se država članica, kada zaposlenik traži da se privatnom poslodavcu naloži plaćanje zaštitne naknade, pozivati na to ili tvrditi da Direktiva ne daje prava s izravnim učinkom protiv poslodavca u okolnostima u kojima bi:

i) privatni poslodavac, da nije bilo propusta države članice da pravilno prenese Direktivu, morao isplatiti zaštitnu naknadu zaposleniku zbog toga što se nije savjetovao u skladu s Direktivom i

ii) ta država članica morala, podložno bilo kojem ograničenju odgovornosti nametnutom jamstvenoj ustanovi države članice u skladu s člankom 4. [Direktive 2008/94], s obzirom na to da je taj poslodavac insolventan, u slučaju u kojem se privatnom poslodavcu naloži plaćanje zaštitne naknade, a on je ne isplati i državi članici se podnese zahtjev za isplatu te zaštitne naknade - zaposleniku platiti tu zaštitnu naknadu u skladu s nacionalnim propisima kojima je prenesena ta direktiva?" 


\section{Presuda Suda EU}

Predmeti Lyttle, Cañas i Woolworths nisu bili formalno spojeni, ali je nezavisni odvjetnik Nils Wahl u svojem mišljenju od 5. veljače 2015. godine ${ }^{27}$ zajedno promatrao u bitnome ista pravna pitanja u sva tri predmeta, dok je Sud EU donio tri odvojene presude.

Tako nezavisni odvjetnik Wahl prvenstveno primjenjuje gramatičku metodu tumačenja te se poziva na obrazloženja iz predmeta Rockfon i Athinaïki Chartopoïa u kojima je već dano tumačenje pojma ,pogon“. Međutim, u tim predmetima radilo se o tumačenju pojma ,pogon“ iz Opcije 1 Direktive 98/59, te je prihvaćeno tumačenje išlo u prilog odnosnim radnicima. U predmetu Woolworths, radilo se o tumačenju pojma ,pogon“" navedenog u Opciji 2 iz Direktive 98/59 u kojem slučaju bi isto tumačenje pojma ,pogon" moglo ići na štetu odnosnih radnika (odnosno ne bi im bila pružena kolektivna zaštita). Stoga je razmatrano pitanje treba li postojeću sudsku praksu mijenjati. Sud EU je prihvatio stajalište nezavisnog odvjetnika Wahla koji je smatrao ključnim dosljedno tumačiti već definirani pojam „pogon“ kako bi se omogućila ujednačena primjena prava Europske unije.

Stoga je Sud EU potvrdio da se pojam ,pogon“ mora jednako tumačiti kod Opcije 1 i kod Opcije 2 iz Direktive 98/59, te da pogon treba tumačiti prema definiciji postavljenoj u predmetu Rockfon, odnosno „kao jedinicu u koju su radnici na koje se otkazivanje odnosi raspoređeni radi obavljanja svojih zadataka. ${ }^{28 "}$ Isto tako, potvrđena je i primjena dodatnih kriterija prethodno definiranih u predmetu Athinaïki Chartopoiïa. Imajući u vidu navedenu definiciju, Sud EU potvrdio je da Opcija 1 i Opcija 2 Direktive 98/59 zahtijevaju da se uzme u obzir otkazivanje provedeno u svakom pogonu razmotreno odvojeno. ${ }^{29}$ Sud EU u presudi navodi da pristup širenja postupka zaštite na sve radnike koji su dobili otkaz tijekom istog restrukturiranja, neovisno o veličini pogona, nije u skladu s ciljem minimalnog usklađivanja iz Direktive 98/59, kojom se ne predviđa kao polaznu točku punu zaštitu za sve otpuštene radnike. Sud EU smatra da bi takvo tumačenje primjene Direktive 98/59 obuhvatilo ne samo skupinu radnika na koje se odnosi kolektivno otkazivanje, nego, ako je potrebno, i samo jednog radnika jednog pogona, i to primjerice pogona koji se nalazi izdvojeno i udaljeno od ostalih pogona istog poduzeća, a što je suprotno pojmu ,kolektivno otkazivanje “. ${ }^{30} \mathrm{U}$ tom kontekstu, potrebno je voditi računa o članku 5. Direktive 98/59, kojim se daje pravo državama članicama da primjene povoljnije pravo za radnike, odnosno da dodijele zaštitu što je Direktiva 98/59 predviđa ne samo radnicima jednog pogona koji predstavljaju višak, nego također svim radnicima na koje se odnosi otkazivanje kod istog poslodavca. ${ }^{31}$

27 Mišljenje nezavisnog odvjetnika Nilsa Wahla u predmetima C-182/13, C-392/13 i C-80/14 dostupno na http://eur-lex.europa.eu/legal-content/HR/TXT/HTML/?uri=CELEX:62013CC0182\&qid=1 473669330641\&from=HR (pregledano 10. IX. 2016.).

28 Predmet Rockfon, paragraf 32.

29 Predmet Woolworths, paragraf 69.

30 Predmet Woolworths, paragraf 64.

31 Predmet Woolworths, paragraf 65 i 66. 


\section{Osvrt na predmet Woolworths}

Prilikom tumačenja pojmova prava Europske unije, kao što je pojam „,pogon“, nezavisni odvjetnik Wahl i Sud EU vodili su računa o ciljevima koji su utjecali na donošenje Direktive 98/59. Tako, u svojem mišljenju nezavisni odvjetnik Wahl prvenstveno primjenjuje teleološku metodu tumačenja i identificira dva važna cilja Direktive 98/59:

- cilj socijalne zaštite, prema kojemu je namjera donošenja Direktive 98/59 bila pružanje osnovne zaštite u pogledu obavješćivanja i savjetovanja s radnicima u slučaju kolektivnog otkazivanja, pri čemu države članice i dalje mogu usvajati mjere povoljnije, ${ }^{32}$ za radnika, te - cilj unutarnjeg tržišta, prema kojem je svrha Direktive 98/59 uskladiti troškove što ih pravila o kolektivnom otkazivanju stvaraju poduzećima u Europskoj uniji. ${ }^{33}$

Cilj socijalne zaštite, kako ga naziva nezavisni odvjetnik Wahl, jest nesporno osnovni cilj donošenja Direktive 98/57. ${ }^{34}$ Sud EU ga je isto istaknuo u presudi u predmetu Woolworths nazivajući ga „,iljem usmjerenim na osiguranje usporedive zaštite prava radnika u državama članicama“.${ }^{35}$ Međutim, čini se da je identificiranje i posebno isticanje „cilja unutarnjeg tržišta“ od strane nezavisnog odvjetnika Wahla potrebno, donekle, izložiti kritici. Navedeni stav nezavisni odvjetnik Wahl izvodi iz ekstenzivnog tumačenja Preambule Direktive 98/59 i zaključuje kako se cilj socijalne zašite ne može odvojiti od cilja unutarnjeg tržišta, te podupire stajalište da je predmetni pojam ,pogon“" potrebno tumačiti ujednačeno, kako bi se povećala transparentnost i predvidivost za poslodavce, koji odluče restrukturirati svoja poduzeća. U tom smislu, nezavisni odvjetnik Wahl u svojem mišljenju citira i literaturu, u kojoj se navodi da je Direktiva $75 / 129^{36}$ (direktiva koja je prethodila Direktivi 98/59) usvojena ,kako bi se spriječila paneuropska društva da kalkuliraju gdje su (odnosno u kojoj su državi članici) troškovi otpuštanja najniži i“ ${ }^{37}$ Iako je nesporno da pravila o kolektivnom otkazivanju radnika i njezine razlike u državama članicama mogu imati određeni utjecaj na funkcioniranje unutarnjeg tržišta, čini se da se definiranjem „cilja unutarnjeg tržišta“, na način na koji to sugerira nezavisni odvjetnik Wahl, preširoko redefiniraju temelji i tumači svrha Direktive 98/59. U presudi u predmetu Woolworths Sud EU nije primijenio sam naziv predmetnog cilja, kako to predlaže nezavisni odvjetnik Wahl, ali ga je donekle prihvatio navodeći da 42.

32 Mišljenje nezavisnog odvjetnika Nilsa Wahla u predmetima Lyttle, Cañas $i$ Woolworths, paragraf

33 Mišljenje nezavisnog odvjetnika Nilsa Wahla u predmetima Lyttle, Cañas $i$ Woolworths, paragraf 51.

34 U obrazloženju Konačnog prijedloga Zakona o izmjenama i dopunama Zakona o radu, PZE 641, drugo čitanje od 12. lipnja 2003. godine navodi da je cilj Direktive 98/59, ,bolja zaštita radnika u slučaju kolektivnog viška“.

35 Predmet Woolworths, paragraf 62 i 63.

36 Op. cit. (bilj 2).

37 Mišljenje nezavisnog odvjetnika Nilsa Wahla u predmetima Lyttle, Cañas $i$ Woolworths, fusnota 30. 
nije samo prvi navedeni cilj svrha donošenja Direktive $98 / 59$, već i „ujednačavanje tereta koje pravila kolektivne zaštite uzrokuju poslodavcima Europske unije“. ${ }^{38}$

U tom kontekstu treba primijetiti da se na prvi pogled stječe dojam kako su tumačenja iz predmeta Woolworths u potpunosti konzistentna $\mathrm{s}$ dotadašnjom praksom Suda EU. Međutim, nakon detaljnije analize, postavlja se pitanje ispravnosti donesenih zaključaka, te je stoga i navedena presuda često citirana u stručnoj literaturi. ${ }^{39}$ Prilikom tumačenja pojmova europskog prava, primjena teleološke metode jest najvažnija. ${ }^{40} \mathrm{U}$ tom smislu, čini se ispravnijim zaključiti da je svrha ujednačavanja prava i troškova poslodavaca u različitim državama članicama (odnosno cilj unutarnjeg tržišta, kako ga u svojem mišljenju naziva nezavisni odvjetnik Wahl) tek podređena osnovnom cilju donošenja Direktive 98/59, odnosno zaštiti radničkih prava. Imajući u vidu tumačenja Suda EU u predmetu Woolworths, poslodavcima stoji na raspolaganju veliki prostor za izbjegavanje svoje obveze i posljedično, umanjenje radničkih prava. Naime, poslodavci mogu paziti da u pojedinom pogonu ne zapošljavaju više od 19 radnika. U tom smislu, nije bitno postoji li uopće prostorna udaljenost pogona od drugih dijelova poduzeća. ${ }^{41}$ Tako primjerice, ako poslodavac upravlja s više trgovina u jednom trgovačkom centru gdje zapošljava manje od 20 radnika, ne bi dolazilo do primjene Direktive 98/59. ${ }^{42}$ Stoga, čini se da tumačenjem predmeta ,pogon" u recentnijoj sudskoj praksi Suda EU nije ostvaren postulat Suda EU iznesen još u predmetu Athinaïki Chartopoiïa, prema kojem je Direktiva 98/59 usmjerena na društveno-gospodarske učinke koje kolektivna otkazivanja mogu uzrokovati u lokalnom kontekstu i određenom društvenom okružju. ${ }^{43}$ Čak, ako bi se i prihvatilo tumačenje Suda EU, prema kojem se stavlja u isti rang dva prethodno obrazložena cilja donošenja Direktive 98/59, i dalje postoje otvorena pitanja u odnosu na prihvaćeno tumačenje. Naime, ukoliko država članica izabere u svoje nacionalno zakonodavstvo implementirati Opciju 1 iz Direktive 98/59, primjenjujući definicije pojma „pogon“" postavljene u predmetima Rockfon i Athinaïki Chartopoïa, dolazi do široke primjene zaštite u slučaju kolektivnog otkazivanja. Međutim, do potpuno suprotnog efekta dolazi ako država članica odabere Opciju 2 iz Direktive 98/59, u kojem slučaju dolazi do sužene primjene kolektivne zaštite. Upravo su ishodi u predmetima Woolworths i

38 Predmet Woolworths, paragraf 62 i 63.

39 Vidjeti više u člancima: „Der Betriebsbegriff im Sinne der Massenentlassungsrichtlinie“, dr. Stefan Greiner i Maria Hennecken., GPR 6/2015; „Was ist ein Betrieb im Sinne der Massentlasssungsrichtlinie“, prof. dr. Frank Maschmann, Regensburg, EuZA 2015, 488; „,Der europäische Betriebsbegriff“, dr Benecke, Martin i Groß, Nadj, EuZW 15/2015; ,Was ist ein Betrieb im Sinne der Massentlasssungsrichtlinie“, prof. dr. Maschmann, Frank (Regensburg), EuZA 2015, 488; Countouris, Nicola i Koukiadaki, Aristea: „The Purpose of European Labour Law: Floor Of Rights - Or Ceiling?“, dostupno na https:/www.socialeurope. eu/2016/06/purpose-european-labour-law-floor-rights-ceiling/ (pregledano 20. VII. 2016.).

40 Vidjeti više u članku „Der Betriebsbegriff im Sinne der Massenentlassungsrichtlinie“, dr. Stefan Greiner i Maria Hennecken., GPR 6/2015.

41 Predmet Athinaïki Chartopoïa, paragraf 29.

42 Iako nezavisni odvjetnik Nils Wahl u svojem mišljenju u predmetu Woolworths, paragraf 62, smatra da nije nezamislivo smatrati da sve te trgovine čine jednu lokalnu radnu jedinicu.

43 Predmet Athinaïki Chartopoïa, paragraf 51. 
Lyttle dobar pokazatelj toga, u kojim slučajevima je kolektivnu zaštitu propisanu Direktivom 98/59 u predmetu Woolworths izgubilo preko 4,500 radnika i u predmetu Lyttle 1,000 radnika. U konačnici dolazimo do efekta koji se nastojalo izbjeći - ne postoji usporediva zaštita radnika, odnosno postoji nesklad između obveza poslodavaca u različitim državama članicama.

\section{USKLAĐENOST DEFINICIJA KOLEKTIVNOG VIŠKA RADNIKA PO HRVATSKOM I EUROPSKOM PRAVU}

\subsection{Definicija kolektivnog viška radnika prema Zakonu o radu}

Prema odredbama trenutno važećeg Zakona o $\operatorname{radu}^{44}$ koji je stupio na snagu dana 7. kolovoza 2014. godine (dalje u tekstu kao: ZOR 2014), u slučaju kolektivnog otkazivanja radnici imaju određeni viši stupanj zaštite, odnosno poslodavci imaju dodatne obveze i troškove. ${ }^{45}$

Sukladno članku 127. ZOR-a 2014, do primjene odredbi o kolektivnom višku radnika dolazi ukoliko bi kod „,poslodavca... u razdoblju od devedeset dana mogla prestati potreba za radom najmanje dvadeset radnika od kojih bi poslovno uvjetovanim otkazom prestali ugovori o radu najmanje petorice radnika. “. U višak radnika ubrajaju se radnici kojima će radni odnos prestati poslovno uvjetovanim otkazom ugovora o radu i sporazumom poslodavca i radnika na prijedlog poslodavca.

Ukoliko navedeni pragovi budu dosegnuti, poslodavac je dužan pravodobno i na način propisan ZOR-om 2014, savjetovati se s radničkim vijećem radi postizanja sporazuma u svrhu otklanjanja ili smanjenja potrebe za prestankom rada radnika, te o provedenom savjetovanju obavijestiti nadležnu javnu službu zapošljavanja (Hrvatski zavod za zapošljavanje) ${ }^{46} \mathrm{ZOR}$-om 2014 je nadalje propisano da radnicima koji su utvrđeni viškom, radni odnos ne smije prestati tijekom razdoblja od trideset dana od dana dostave obavijesti nadležnoj javnoj službi za zapošljavanje. Nadležna javna služba za zapošljavanje može poslodavcu pisano naložiti odgodu provođenja otkazivanja svim ili pojedinim radnicima, koji su utvrđeni viškom za još najduže trideset dana, ako tijekom produženog roka može osigurati nastavak radnog odnosa

${ }_{44}$ Zakon o radu, Narodne novine, broj 93/14.

45 Više kod Zlatović, Dragan; Malenica, Ivan, Novo hrvatsko radno pravo, Zagreb, 2016., str. 384.; Čavkar, Drako; Frntić, Domagoj Franjo; Gović Penić, Iris; Gruban, Marina; Milković, Darko; Novaković, Nataša; Rožman, Krešimir, Detaljni komentar novog Zakona o radu, 2014., str. 482.

46 Prema Godišnjem Izvješću o radu Hrvatskog zavoda za zapošljavanje (HZZZ) za 2014. godinu (dostupno na http://www.hzz.hr/UserDocsImages/Izvjesce_o_radu_HZZ_2014.pdf, pregledano 15. VII. 2016. godine), tijekom 2014. godine HZZZ je zaprimio 39 programa zbrinjavanja viška radnika, te nakon stupanja na snagu ZOR-a 29 obavijesti poslodavaca o kolektivnom višku radnika, kojima je sveukupno obuhvaćeno 6639 radnika. U usporedbi s 2013. godinom, kada je Zavod zaprimio 107 programa zbrinjavanja viška radnika kojima su bila obuhvaćena 12.843 radnika, broj zaprimljenih programa i obavijesti o kolektivnom višku radnika u 2014. godini smanjio se za 39 (ili 36,4 \%), a broj obuhvaćenih radnika za 6204 (ili 48,3 \%). Podaci za 2015. godinu nisu dostupni. 
Dora Gaži Kovačević: Definicija kolektivnog viška radnika u europskom i hrvatskom radnom... Zbornik radova Pravnog fakulteta u Splitu, god. 54, 3/2017., str. 659.- 682.

radnika. Navedeno znači da poslodavac može započeti s pripremama za otkazivanje, ali da se odluka o otkazu ne može donijeti prije isteka navedenih rokova. ${ }^{47}$

\subsection{Otvorena pitanja vezana uz ocjenu usklađenosti ZOR-a $2014 \mathrm{~s}$ Direktivom 98/59 i praksom Suda EU}

Hrvatski zakonodavac je implementirao Opciju 2 iz Direktive 98/59 u hrvatski Zakon o radu. Međutim, u definiciji kolektivnog viška radnika iz trenutno važećeg članka 127. ZOR-a 2014 (jednako kao i u definicijama koje su bile navedene u prethodnim zakonodavnim rješenjima) izostavljen je dio rečenice iz Direktive 98/59 koji navodi da se kolektivnim otkazom smatra otkaz dan u razdoblju od 90 dana, najmanje 20 radnika „...bez obzira na broj inače zaposlenih radnika u pojedinom pogonu" (engleski prijevod: ,whatever the number of workers normally employed in the establishments in question"). Na taj način, broj viška radnika se utvrđuje na razini poslodavca, te je osigurana šira zaštita u slučaju kolektivnog otkazivanja. Drugim riječima, dolazi do primjene povoljnijeg prava za radnike, s obzirom da prilikom izračuna pragova treba voditi računa o ukupnom broju radnika, koji bi mogli biti utvrđeni viškom kod određenog poslodavca.

Imajući u vidu u prethodnim poglavljima ovog rada izneseno tumačenje Direktive 98/59 i prakse Suda EU, u ovom poglavlju se analiziraju dva otvorena pitanja. Prvo, je li hrvatski zakonodavac prilikom implementacije definicije kolektivnog viška radnika iz Direktive 98/59 primijenio povoljnije uređenje predmetnog pitanja u smislu članka 5. Direktive 98/59. Drugo, može li se prilikom implementacije direktive u potpunosti zanemariti njezin bitan dio koji upućuje na pojam ,pogon“.

Kako bi se razmotrila navedena pitanja, potrebno je prvenstveno utvrditi je li do zakonskog rješenja u hrvatskom Zakonu o radu došlo iz prave namjere zakonodavca da se povoljnije uredi pitanje kolektivnog viška radnika i tako izostavi referencu na pojam "pogon" ili je do takvog rješenja došlo iz jednostavnog previda ili čak zbog nedovoljno jasnog prijevoda Direktive 98/59. U zakonodavnoj proceduri prilikom donošenja izmjena i dopuna Zakona o radu iz 2003. godine ${ }^{48}$ (dalje u tekstu kao: ZOR 2003), kada je Direktiva 98/59 po prvi put implementirana u hrvatsko zakonodavstvo, ${ }^{49}$ navedeno je da je definicija kolektivnog viška radnika iz ZOR-a 2003 u potpunosti usklađena s definicijom iz Opcije 2 Direktive 98/59. Navedeno nije u potpunosti točno, s obzirom da je referenca na pojam, ,pogon“ u tekstu ZOR-a 2003 izostavljena.

47 Gović Penić, Iris: „Kolektivni višak radnika“, Pravo i porezi (2014.), 11; str. 5.

48 Zakon o izmjenama i dopunama Zakona o radu, Narodne novine, broj 114/03.

49 Konačni prijedlog zakona o izmjenama i dopunama Zakona o radu, P.Z.E. br 641 od 13. lipnja 2003. godine, zajedno s Izjavom o usklađenosti Konačnog prijedloga zakona o izmjenama i dopunama Zakona o radu s Acquis Communautaireom i Usporednim prikazom podudaranja odredbi (nacrta) prijedloga propisa s propisom EU. 
Zanimljivo je da u objašnjenju prijedloga predmetnog članka ZOR-a $2003,{ }^{50}$ predlagatelj obrazlaže obveze poslodavca prilikom kolektivnog otkazivanja pojašnjavajući da određene obveze postoje ,bez obzira na veličinu poslodavca“ ${ }^{51}$ Engleski termin za pogon (,establishment“) koji se navodi u Direktivi 98/59, može se na različite načine prevesti na hrvatski jezik - tako da označava cijelo društvo poslodavca ili samo njegov dio (odnosno postrojenje ili pogon). ${ }^{52}$ Stoga je moguće da je prilikom prijevoda Direktive 98/59 došlo do omaške, te je terminu „establishment" dano šire značenje, na način da se termin „establishment” preveo kao „poslodavac”. Kao što je prethodno navedeno, Sud EU je još 2007. godine pojasnio u predmetu Athinaïki Chartopoiïa da su pojmovi „poduzeće” (engleski termin: ,undertaking”) i pojam ,pogon" različiti.

Nadalje, u obrazloženju prijedloga ZOR-a 2003 i pratećem usporednom prikazu podudaranja odredbi ZOR-a 2003 i Direktive 98/59 ne navodi se da je izvršeno i usklađivanje sa člankom 5. Direktive 98/59, odnosno da je Hrvatska odlučila proširiti područje kolektivne zaštite radničkih prava i primijeniti povoljnije pravo za radnike. Na sličan način, u zakonodavnoj proceduri za donošenje Zakona o radu 2009. godine (dalje u tekstu kao: ZOR-a 2009) ${ }^{53}$ izričito je navedeno da je članak 5. Direktive 98/59, ,neprimjenjiv”.

Stoga, u odnosu na prvo postavljeno pitanje, čini se da postoji više argumenata u prilog tumačenju da se ipak radilo o previdu zakonodavca, a ne o stvarnoj namjeri zakonodavca da se predmetno pitanje kolektivnog otkazivanja uredi na povoljniji način za radnike. Države članice nisu dužne prilikom implementacije direktive detaljno obrazlagati iz kojeg razloga će povoljnije urediti određeno pitanje. Međutim, imajući u vidu hrvatsku zakonodavnu proceduru, u kojoj se detaljno obrazlažu prijedlozi izmjene i dopuna zakona, te izrađuje usporedni prikaz usklađenosti odredbi prijedloga zakona s direktivom, za očekivati je bilo da će hrvatski predlagatelj zakona barem dati određeno obrazloženje. Ovako ostaje nejasno i podložno različitoj interpretaciji iz kojeg razloga se dio formulacije iz Direktive 98/59 izostavio, iako se u obrazloženju prijedloga zakona i dalje taj dio indirektno navodi, te zašto je ključan članak za primjenu povoljnijeg prava (članak 5. Direktive 98/59) označen kao neprimjenjiv.

Ipak, neovisno o razlozima takvog uređenja, nesporno je da je definicija kolektivnog viška radnika u ZOR-u 2014 povoljnija za radnike, što bi trebalo biti u skladu sa člankom 5. Direktive 98/59. Naime, Direktiva 98/59 ne zahtijeva, ali niti

50 Konačni prijedlog zakona o izmjenama i dopunama Zakona o radu, P.Z.E. br 641 od 13. lipnja 2003. godine, str. 50 .

51 Navedenog izričaja nema u samom tekstu predloženog i u konačnici, usvojenog ZOR-a 2003, kao niti u kasnije usvojenim definicijama kolektivnog otkazivanja.

52 Vidi prijevod na http://www.eudict.com/?lang=engcro\&word=establishment (pregledano 11. IX. 2016.).

53 Konačni prijedlog zakona o izmjenama i dopunama Zakona o radu, P.Z.E. br. 461 od 22. listopada 2009. godine zajedno s Izjavom o usklađenosti Konačnog prijedloga zakona o izmjenama i dopunama Zakona o radu s Acquis Communautaireom i Usporednim prikazom podudaranja odredbi (nacrta) prijedloga propisa s propisom EU; Zakon o radu objavljen u Narodnim novinama broj 149/2009. 
ne zabranjuje zbrajanje broja otkaza u svim poslodavčevim pogonima radi provjere jesu li dosegnuti pragovi propisani Direktivom 98/59. Na državama članicama je da odluče smatraju li potrebnim povećati razinu zaštite temeljem članka 5. Direktive 98/59, pod uvjetom da će to u svakoj situaciji biti povoljnije za radnike koji su dobili otkaze. ${ }^{54}$

Ostaje, međutim, otvoreno drugo pitanje, može li se prilikom usklađivanja s Opcijom 2 iz Direktive 98/59 u potpunosti zanemariti njezin bitan dio koji upućuje na pojam "pogon". Navedeno pitanje dolazi još više do izražaja u kontekstu recentne prakse Suda EU. Nezavisni odvjetnik Wahl u svojem mišljenju u predmetnu Woolworths predlaže definiciju pogona, te navodi da to ,ne onemogućava države članice da usvajaju provedbena pravila temeljem tog pojma (engleski prijevod: on the basis of that concept) koja su, bez smanjivanja razine minimalne zaštite, povoljnija za radnike. Nacionalni sud mora potvrditi da to doista i jest slučaj." ${ }^{\text {"55 }}$ Nadalje, Sud EU u istom predmetu navodi da - iako države članice imaju pravo predvidjeti pravila povoljnija za radnike na temelju članka 5. Direktive 98/59 - ,one su međutim vezane autonomnim i ujednačenim tumačenjem pojma prava Unije, kao što je pojam „pogon“ iz Opcije 1 i Opcije 2 Direktive 98/59.56

Drugim riječima, države članice mogu svojim zakonodavstvom osigurati veću zaštitu radnika propisujući, primjerice, da se prilikom izračuna kolektivnog viška radnika mora voditi računa o svim poslodavčevim pogonima. Ipak, iz navedenih stajališta moglo bi se zaključiti kako je prilikom prijevoda, odnosno implementacije Direktive 98/59 bilo potrebno voditi računa o značenju pojma „pogon“, koji predstavlja pojam europskog prava i tumačenjem kojeg su se nacionalni sudovi dužni pridržavati. S druge strane, činjenica što ZOR 2014 ne sadrži pojam ,pogon“ u svojoj definiciji kolektivnog otkazivanja, ne znači samo po sebi da je Hrvatska povrijedila pravo Europske unije.

\subsection{Dužnost i odgovornost države po pravu Europske unije}

Za očekivati je da će odgovor na ova otvorena pitanja usklađenosti hrvatske definicije kolektivnog viška radnika s onom iz Direktive 98/59 dati u prvom redu hrvatski sudovi, čija je ustavna dužnost štititi subjektivna prava utemeljena na pravnoj stečevini Europske unije.$^{57}$ Uloga hrvatskih sudova je važna prvenstveno 61.

54 Mišljenje nezavisnog odvjetnika Nilsa Wahla u predmetima Lyttle, Cañas $i$ Woolworths, paragraf

55 Mišljenje nezavisnog odvjetnika Nilsa Wahla u predmetima Lyttle, Cañas $i$ Woolworths, paragraf 82. U predmetnom Mišljenju, paragraf 67, navodi se: „Sada države članice mogu temeljem članka 5. Direktive 98/59 pružiti radnicima zaštitu tako da, primjerice, produlje vrijeme koje je dopušteno za zbrajanje otkaza na koje se direktiva odnosi. Međutim, direktiva nije smörgåsbord, što znači da ne može svatko birati što ga je volja! Države članice ne mogu poništiti učinak povećane razine zaštite tako da ju smanje u drugim pogledima, primjerice, užim tumačenjem pojma „otkazivanje“. Kao ni metode za izračunavanje pragova - te, stoga, ni sami pragovi - taj pojam nije unutar njihove diskrecije. "

56 Predmet Woolworths, paragraf 67.

57 Članak 141c. Ustava Republike Hrvatske. 
prilikom dužnosti interpretacije zakona u svijetlu direktive, te mogućnosti (ili u nekim slučajevima dužnosti) postavljanja zahtjeva Sudu EU za tumačenje prava Europske unije. U slučaju povrede odredbi direktive, moguće je pokretanje postupka zbog povrede prava EU protiv Hrvatske, te postoje slučajevi u kojima Hrvatska može odgovarati za štetu. Ova pitanja se dalje detaljno obrazlažu u ovom poglavlju, te se iznosi i prijedlog de lege ferenda.

Prema pravu Europske unije, država je dužna ugraditi direktivu u nacionalno pravo. Međutim, država nije samo zakonodavac već i sudovi (pa i druga državna tijela, te primjerice pravne osobe s javnim ovlastima, sveučilišta i škole). Naime, u predmetu Foster $^{58}$ Sud EU je vrlo široko interpretirao pojam ,države“ za potrebe vertikalne izravne primjene direktiva.$^{59}$ Predmetna definicija je potom doživila širu primjenu u pravu EU, te se prema tome država definira kao „organizacije ili tijela koja su pod autoritetom ili kontrolom države ili imaju specijalne ovlasti izvan onih koje rezultiraju iz uobičajenih pravila primjenjivih među pojedincima". ${ }^{60}$ Stoga, neovisno o tome kako je hrvatski zakonodavac definirao kolektivni višak radnika, te iz kojih razloga je tako postupio, još uvijek postoji prilika da hrvatski sudovi kroz interpretaciju drugačije implementiraju direktivu.

U predmetima kolektivnog viška radnika najčešće se radi o horizontalnim situacijama, odnosno o odnosu između dva pojedinca (poslodavca kao pravne osobe i radnika kao fizičke osobe) kada direktive nemaju izravni učinak. Drugim riječima, pojedinac se ne može pozivati na direktivu protiv drugog pojedinca, jer direktive ne mogu stvarati obveze za pojedince, već samo za države, pa stoga u horizontalnoj situaciji ne može nastati ni pravo za pojedinca. ${ }^{61} \mathrm{U}$ tom smislu, niti Direktiva 98/59 nema horizontalan izravan učinak. ${ }^{62}$ Međutim, prema metodi o posrednom ili interpretativnom učinku europskog prava, ${ }^{63}$ hrvatski sudovi moraju hrvatsko pravo interpretirati u skladu s europskom normom. Drugim riječima, hrvatski sudovi su dužni primjenjivati ne samo hrvatsko pravo koje implementira predmetnu direktivu, već u svakom trenutku moraju biti svjesni ciljeva direktive na kojoj se nacionalno pravo -,koje provodi direktivu - temelji, te moraju biti

58 Predmet Foster $i$ ostali v. Bristish Gas, C-188/89 (1990.), ECR I-3313, presuda od 12. VII. 1990.

59 O vertikalnim se situacijama radi kada se pojedinac poziva na direktivu protiv države. Sudska je praksa uspostavila pravilo po kojem direktive mogu imati izravni učinak u vertikalnim, ali ne i u horizontalnim odnosima.

60 Ibid, paragraf 18.

${ }_{61}$ Predmet M. H. Marshall v. Southampton and South-West Hampshire Area Health Authority, C-152/84, (1886.) ECR 723, paragraf 48. 80 .

62 Mišljenje nezavisnog odvjetnika Nilsa Wahla u predmetima Lyttle, Cañas i Woolworths, paragraf

63 Metoda o posrednom (interpretativnom) učinku direktiva razvijala se uglavnom u predmetima $u$ kojima direktive nisu imale izravni učinak, te se stoga interpretativnu obvezu često smatra supsidijarnom u odnosu na obvezu izravne primjene direktive. Posredni ili indirektan učinak stvara obvezu za nacionalni sud da nacionalno pravo interpretira u skladu s europskom normom. Ukoliko postoji više mogućih značenja iste pravne norme, nacionalni je sud dužan dati normi ono značenje kojim se ostvaruje cilj što ga želi postići europska norma. Vidi više kod Ćapeta, Tamara; Rodin, Siniša, Osnove prava Europske unije, Gradivo za cjeloživotno obrazovanje pravnika, Zagreb, 2009., str. 46. 
Dora Gaži Kovačević: Definicija kolektivnog viška radnika u europskom i hrvatskom radnom... Zbornik radova Pravnog fakulteta u Splitu, god. 54, 3/2017., str. 659.- 682.

sposobni procijeniti je li nacionalno pravo u potpunosti i pravovremeno ispunilo ciljeve propisane direktivom. ${ }^{64}$

Sukladno tome, hrvatski sudovi nisu dužni tumačiti ZOR 2014 niti na način na koji je to zakonodavac možda zamislio prilikom donošenja. U tom kontekstu, nužno je napomenuti da -iako je i dalje formalno-pravno Hrvatski sabor nadležan za davanje vjerodostojnog tumačenja zakona ${ }^{65}$ na inicijativu predlagatelja zakonavjerodostojno tumačenje podložno je ozbiljnoj kritici pravne teorije i prakse. ${ }^{66}$ To je ovdje navedeno prvenstveno iz razloga što je vjerodostojno tumačenje zakona od strane Hrvatskog sabora suprotno ustavnom načelu diobe vlasti i vladavine prava, jer zadire u nadležnost sudbene vlasti i krši ustavnu zabranu retroaktivnosti zakonodavstva. ${ }^{67}$ Stoga se i u praksi navedeni institut sve rjeđe koristi. ${ }^{68}$

Ako bi, međutim, kod hrvatskog suda postojale dvojbe u tumačenju odredbi europskog prava, hrvatski sud može postupiti sukladno odredbama Zakona o parničnom postupku ${ }^{69}$ prekinuti postupak, te podnijeti zahtjev Sudu EU o tumačenju prava Europske unije. UFEU ${ }^{70}$ propisuje da - ako se takvo pitanje pojavi pred bilo kojim sudom države članice - taj sud može, smatra li da je odluka o tom pitanju potrebna kako bi mogao donijeti presudu, zatražiti od Suda EU da o tome odluči. Važno je istaknuti kako je nacionalni sud, protiv čijih odluka prema nacionalnom pravu nema pravnog lijeka (primjerice Vrhovni sud Republike Hrvatske), dužan uputiti ovo pitanje Sudu. ${ }^{71}$

Kao što je prethodno navedeno, direktive moraju biti pravilno i u roku prenesene u nacionalno pravo. Za slučaj da to nije tako, UFEU ${ }^{72}$ regulira i postupak zbog povrede prava EU (engl. infringement procedure), ako država članica ,nije ispunila neku obvezu na temelju Ugovora", u kojem slučaju Europska komisija ili država članica mogu pokrenuti postupak pred Sudom EU protiv druge države članice.

64 Predmet Marleasing SA protiv La Comercial Internacional de Alimentacion SA, C-106/89 (1990.) ECR I-04135, presuda od 13. studenog 1990. u paragrafu 8 presude se navodi: „....) Iz toga slijedi da je, prilikom primjene nacionalnoga prava, bilo da su odredbe o kojima je riječ donesene prije ili poslije direktive, nacionalni sud koji ga je pozvan interpretirati obvezan to učiniti što je više moguće u svjetlu teksta i svrhe direktive, kako bi postigao rezultat kojemu teži direktiva, te time postupio u skladu s trećim stavka članka 189. Ugovora.“”

65 Poslovnik Hrvatskog sabora (Narodne novine 81/13), čl. 208.

66 Vidi više kod Rodin, Siniša: „Demokratsko-pluralistička kritika instituta tzv. vjerodostojnog tumačenja“, Informator 53 (2005.), 5337-5338; 1-4; Dr. Dc. Antić, Teodor: „Vjerodostojno tumačenje zakona“", Zbornik Pravnog fakulteta Sveučilišta u Rijeci, (1991.), v. 36, br. 1., 619-644 (2015.).

67 Rodin, Siniša: „Demokratsko-pluralistička kritika instituta tzv. vjerodostojnog tumačenja“, Informator 53 (2005.), 5337-5338; 1-4

68 Od 1998. godine, u Narodnim je novinama objavljeno 17 vjerodostojnih tumačenja, s time da je zadnje objavljeno 2014. godine.

69 Zakon o parničnom postupku (Službeni list SFRJ 4/1977, 36/1977, 36/1980, 6/1980, 69/1982, 43/1982, 58/1984, 74/1987, 57/1989, 20/1990, 27/1990, 35/1991 Narodne novine 53/1991, 91/1992, $112 / 1999,129 / 2000,88 / 2001,117 / 2003,88 / 2005,2 / 2007,96 / 2008,84 / 2008,123 / 2008,57 / 2011,25 / 2013$, 89/2014), članak 213.

70 Članak 267. stavak 2. UFEU-a.

71 Članak 267. stavka 3. UFEU-a.

72 Članci od 258. do 260. UFEU-a. 
Povreda „Ugovora“ o kojoj govori UFEU ne podrazumijeva samo povredu odredbi sadržanih u samim osnivačkim ugovorima, već ukupnog prava utemeljenog na tim ugovorima, pa se može odnositi na, primjerice, povredu odredbi direktive. ${ }^{73}$ Prilikom pokretanja postupka, Europska komisija može djelovati na vlastitu inicijativu ili temeljem pritužbe pojedinaca. Tijekom 2015. godine tako je protiv Hrvatske pred Europskom komisijom (u predsudskoj fazi postupka) bio otvoren 21 postupak zbog povrede prava EU, a od toga niti jedan iz područja radnog zakonodavstva. ${ }^{74}$ S obzirom na to da je definicija kolektivnog viška radnika iz ZOR 2014 od 2003. godine u hrvatskom zakonodavstvu, za pretpostaviti je da je tijekom pristupnih pregovora Hrvatske Europskoj uniji izvršena načelna ocjena usklađenosti hrvatskog radnog s europskim zakonodavstvom, te da Europska komisija nije imala bitnih zamjerki na definiciju kolektivnog viška radnika u smislu da bi zahtijevala njezinu izmjenu. Navedeno ipak, ne znači samo po sebi da je predmetna definicija usklađena, jer se u pregovorima ne ide u takve detalje. Stoga, zanimljivo bi bilo pratiti na koji bi način Europska komisija, pa eventualno i Sud EU, postupili u slučaju pokretanja postupka zbog povrede prava EU.

U konačnici, država može postati odgovorna za štetu učinjenu pojedincu povredom neke obveze koja proizlazi iz europskog prava, pa tako i za neprimjenu ili nepravilnu primjenu direktive. Načelo odgovornosti države za štetu pojedincu nije izričito predviđeno primarnim niti sekundarnim pravom, već je razvijeno kroz sudsku praksu uz doktrine izravnog i posrednog učinka. U praksi navedeno znači da građanin Republike Hrvatske može pred domaćim sudovima tražiti da mu država naknadi štetu zbog toga što, primjerice Hrvatski sabor ili određeni sud nisu izvršili neku obvezu utemeljenu u pravu Europske unije, čime je tom građaninu onemogućeno da uživa subjektivno pravo koje mu dodjeljuje norma europskog prava. U sudskoj praksi razvijeni su i uvjeti koji moraju biti ispunjeni za odgovornost države za štetu. ${ }^{75}$ Međutim, izvan okvira ovog rada ulazi ocjena bi li traženi uvjeti uopće načelno mogli biti ispunjeni, što bi prvenstveno ovisilo o okolnostima konkretnog slučaja.

Kao prijedlog de lege ferenda, bilo bi svakako poželjno da i hrvatski zakonodavac uskoro detaljno razmotri pitanje usklađenosti definicije kolektivnog viška radnika po hrvatskom i europskom pravu, ponovno ocijeni ciljeve koje se želi postići kolektivnom zaštitom, te predloži novu definiciju koja će ukloniti sve nedoumice. Navedeno je posebno važno radi izbjegavanja mogućnosti različitih tumačenja i potencijalnog odugovlačenja sudskih postupaka. Ukoliko je cilj zakonodavca i u

73 Vidi više kod Craig, Paul; De Búrca Gráinne: EU Law, Text, Cases and Materials, Sixth Edition, Oxford, 2015., str. 429.

74 Vidi više u Godišnjem Izvještaju Europske komisije za 2015. „Monitoring the Application of European Union Law", dostupan na http://ec.europa.eu/atwork/applying-eu-law/docs/annual_report_33/ country_sheet_hr_en.pdf(pregledano 08. IX. 2016.).

75 Za nastanak odgovornosti države u konkretnom je slučaju potrebno da se ispune sljedeći uvjeti: (1) da je prekršena norma prava Zajednice imala za svrhu dodjelu subjektivnog prava pojedincu, (2) da je povreda dovoljno ozbiljna, i (3) da postoji izravna uzročna veza između povrede norme i štete nastale pojedincu. Vidi više kod Ćapeta, Tamara, „Odgovornost države za štetu u pravu Europske zajednice“, Zbornik Pravnog fakulteta u Zagrebu 53 (2003.), 3-4. 
Dora Gaži Kovačević: Definicija kolektivnog viška radnika u europskom i hrvatskom radnom... Zbornik radova Pravnog fakulteta u Splitu, god. 54, 3/2017., str. 659.- 682.

budućnost zadržati povoljnije uređenje radničkih prava u slučaju kolektivnog viška radnika, bilo bi najjednostavnije jasno propisati da se prilikom izračuna pragova treba voditi računa o svim pogonima ili poslovnim jedinicama poslodavca. U obrazloženju prijedloga zakona isto tako treba nedvojbeno navesti da se radi o povoljnijem uređenju u smislu članka 5. Direktive 98/59.

\subsection{Posljedice nepostupanja po ZOR-u 2014}

Imajući u vidu prethodno obrazložena otvorena pitanja i mogućnost različitog tumačenja pragova prilikom izračuna viška radnika u slučaju kolektivnog viška radnika pozivajući se na pravo Europske unije, potrebno je razmotriti koju zaštitu po ZOR-u 2014 imaju radnici, ako je poslodavac bio dužan primijeniti odredbe o kolektivnom višku radnika, a nije. U tom slučaju, nesporno je da svaki radnik može osporavati dopuštenost otkaza navodeći da poslodavac nije primijenio odredbe o kolektivnom višku radnika, te da su zbog toga odluke o otkazu nedopuštene.

Potrebno je, međutim, posebno razmotriti slučaj, ako bi poslodavac prilikom donošenje odluke o kolektivnom višku radnika, propustio provesti savjetovanje s radničkim vijećem. ZOR 2014 propisuje da je bilo koja odluka poslodavca važna za položaj radnika, pa tako i ona o otkazima, donesena protivno odredbama ZOR-a 2014 o obvezi savjetovanja, ništetna odnosno ne proizvodi pravne učinke. Iako sud na ništetnost pazi po službenoj dužnosti i na nju se može pozivati svaka zainteresirana osoba, pitanje isticanja ništetnosti zahtjeva detaljniju analizu u svjetlu recentne hrvatske sudske prakse. Naime, u postupku tužitelja Radničko vijeće Hrvatskog Telekoma d.d. protiv tuženika Hrvatski Telekom d.d., Županijski sud u Zagrebu ${ }^{76}$ zauzeo je stajalište, koje je naknadno potvrdio i Vrhovni sud Republike Hrvatske, ${ }^{77}$ prema kojem se radničkome vijeću ne može priznat položaj stranke (ius standi in iudicio) u postupcima radi pobijanja programa zbrinjavanja viška radnika. ${ }^{78}$ Ustavni sud Republike Hrvatske je svojom odlukom od 25. svibnja 2016. godine ${ }^{79}$ utvrdio da u predmetnom postupku nije bilo povrijeđeno pravo na pravično suđenje zajamčeno člankom 29. stavkom 1. Ustava Republike Hrvatske, s obzirom da u tumačenju i primjeni mjerodavnog prava nije utvrđena samovolja ili arbitrarnost.

76 Rješenje Županijskog suda u Zagrebu, Gžr-2174/13-2 od 11. ožujka 2014. godine.

77 Rješenje Vrhovnog suda, Revr-943/14-4 od 11. veljače 2015. godine.

78 Činjenice relevantnog slučaja datiraju iz 2012. godine kada je Hrvatski Telekom d.d. donio odluku o kolektivnom višku 450 radnika i proveo zakonom propisan postupak. Radničko vijeće Hrvatskog Telekoma d.d. smatralo je da je Program zbrinjavanja viška radnika za 2012. godinu donesen protivno mjerodavnim odredbama tada primjenjivog ZOR-a 2009 i kolektivnog ugovora te podnio tužbu Općinskom radnom sudu u Zagrebu radi utvrđenja ništetnosti Programa. Nakon provedenog dokaznog postupka, Općinski radni sud u Zagrebu odbio je tužbeni zahtjev, smatrajući da Program sadrži sve elemente propisane zakonom i da je donesen sukladno propisanoj proceduri. Županijski sud u Zagrebu, odlučujući o žalbi tužitelja, ukinuo je prvostupanjsku presudu i odbacio tužbu, navodeći kako je prvostupanjski sud pogrešno zaključio da Zakon o radu iz 2009. godine priznaje radničkom vijeću stranačku sposobnost (ius standi in iudicio) u postupcima radi pobijanja programa zbrinjavanja viška radnika. Vrhovni sud Republike Hrvatske predmetno je stajalište potvrdio odlučujući o reviziji.

79 Odluka Ustavnog suda Republike Hrvatske od 25. svibnja 2016. godine, broj: U-III-4883/2015. 
U ZOR-u 2014 (kao niti u predmetnom slučaju primjenjivom ZOR-u 2009) nisu naznačene konkretne situacije kada radničko vijeće može biti stranka u postupku, već je naznačeno opće pravilo o nastupanju radničkog vijeća pred sudom, prema kojem radničko vijeće ima položaj stranke u postupku pred sudom samo u onim postupcima u kojima je to izričito propisano odredbama zakona, drugog propisa ili kolektivnog ugovora. ${ }^{80}$ Pregledom sudske prakse koja je prethodila predmetu Hrvatski Telekom, može se zaključiti da je u cijelom nizu slučajeva utvrđeno da radničko vijeće ima stranačku sposobnost. ${ }^{81}$ U predmetu Hrvatski Telekom, Ustavni sud je pozivanje na takvu prethodnu sudsku praksu ocijenio irelevantnom za ocjenjivanje konkretne ustavne tužbe ${ }^{82}$ smatrajući da radničko vijeće nema potrebna ovlaštenja i obveze prilikom donošenja programa zbrinjavanja viška radnika.

S obzirom na navedeno, postavlja se pitanje predstavlja li ovaj recentni stav Vrhovnog suda zaokret u postojećoj sudskoj praksi, koji može imati za posljedicu značajno ograničavanje (ili čak onemogućavanje) radničkog vijeća da prava zajamčena zakonom, drugim propisom ili kolektivnim ugovorom faktički i ostvari. Nadalje, upitno je na koji način će sudska praksa u budućnosti tumačiti stranačku sposobnost radničkog vijeća u drugim sličnim situacijama, a posebice onima u kojima su potencijalno povrijeđena prava većeg broja radnika. S obzirom da se radi o recentnoj sudskoj praksi, u ovom trenutku je teško procijeniti budući smjer koji će sudovi zauzeti. Međutim, analizirajući odredbe ZOR-a 2009 koje se odnose na ovlaštenja radničkog vijeća prilikom donošenja programa zbrinjavanja viška radnika, primjećuje se da su njegova ovlaštenja i obveze, pored opće obveze savjetovanja, zaista vrlo limitirana i obuhvaćaju pravo radničkog vijeća da nadležnoj javnoj službi zapošljavanja i poslodavcu uputi svoje primjedbe i prijedloge o već dostavljenom programu zbrinjavanja viška radnika. ${ }^{83}$ Stoga, u konkretnoj situaciji može se opravdati stav Županijskog odnosno Vrhovnog suda, ali takav stav se ne smije analogno primjenjivati u budućim sličnim sudskim sporovima bez detaljnog razmatranja okolnosti pojedinog slučaja i konteksta zakonskog okvira. Osim toga, predmetna sudska praksa je ograničene primjene, s obzirom na to da je ZOR-om

80 Sukladno odredbi čl. 154. st. 1. Zakona o radu iz 2009. godine (odredba odgovara članku 155. ZOR 2014), radničko vijeće može tužiti ili biti tuženo samo na temelju ovlaštenja, odnosno obveza utvrđenih ovim ili drugim zakonom, drugim propisom ili kolektivnim ugovorom. Zakonom (člankom 147. Zakon o radu iz 2009. godine odnosno člankom 148. ZOR 2014) propisana su temeljna ovlaštenja radničkog vijeća da štiti i promiče interese radnika zaposlenih kod određenog poslodavca, savjetovanjem, suodlučivanjem ili pregovorima s poslodavcem ili od njega opunomoćenom osobom, o pitanjima važnima za položaj radnika te da pazi na poštovanje zakona o radu, pravilnika o radu, kolektivnih ugovora te drugih propisa.

${ }_{81}$ Koji se primjerice odnose na postupak radi poništenja izbora za radničko vijeće (VSRH, Gž 12/092 od 18. III. 2009.), u postupku u kojemu se zahtijeva zabrana štrajka ako je radničko vijeće sudjelovalo u pripremanju ili ostvarenju štrajka (VSRH, Gž 42/1999-2 od 10. V. 2000.), radi oglašavanja da se nezakonit pravilnik o radu ili neke njegove odredbe oglase nevažećim (VSRH, Revr-721/05-2 od 25. VII. 2007.), radi nadomještanja sukladnosti radničkog vijeća na neku odluku (VSRH, Revr-217/02-2 od 8. V. 2002.) i u drugim slučajevima kada radničko vijeće postupa na temelju njegovih ovlaštenja ili obveza. Vidjeti više kod Cavrak, Darko; Gruban, Marina, ,Stranačka sposobnost radničkog vijeća, pravo radničkog vijeća na odabir punomoćnika i trošak zastupanja radničkog vijeća po punomoćniku odvjetniku“, Radno pravo, br. 5, 2012., str. 17.

82 Op. cit. (bilj 79), točka 8.

83 Članak 121. 
2014 ukinuta obveza poslodavca da donese program zbrinjavanja viška radnika prilikom kolektivnog otkazivanja.

Stoga potencijalnu ništetnost odluke u otkazu donesene bez poštovanja prethodne zakonske obveze savjetovanja s radničkim vijećem, mora imati pravo isticati radničko vijeće, odnosno mora mu se u takvom sudskom postupku priznati stranačka sposobnost. S obzirom na jasna zakonska ovlaštenja radničkog vijeća u postupku savjetovanja i sudsku praksu koja je prethodila ovdje obrazloženoj odluci Vrhovnog suda,${ }^{84}$ bilo bi vrlo nelogično i teško za obrazložiti ako bi radničkom vijeću bila uskraćena stranačka sposobnost u takvim postupcima. Takav stav bi imao vrlo negativne posljedice za zaštitu radničkih prava. Primjerice, ako prilikom otkazivanja 300 ugovora o radu, poslodavac ne bi proveo postupak savjetovanja znajući da jedino radnik (ili eventualno treća zainteresirana osoba) može isticati nedopuštenost otkaza, jer radničkom vijeću stranačka sposobnost nije priznata, za očekivati je da bi prije prihvatio rizik davanja nedopuštenih otkaza smatrajući malo vjerojatnim da će svi, ili većina radnika, pokrenuti dugotrajne sudske postupke.

Važno je upozoriti i na nelogično rješenje iz ZOR 2014, koji ne propisuje prekršajne odredbe vezane uz propuste poslodavca prilikom otkazivanja ugovora o radu u postupku kolektivnog viška radnika. Neovisno o mogućnosti pokretanja sudskog postupka u kojem se može isticati nedopuštenost otkaza radi takvog propusta poslodavca, trebalo bi se svakako raditi i o prekršajnoj odgovornosti poslodavca radi zaštite javnog poretka i društvene discipline. ${ }^{85}$

\section{ZAKLJUČAK}

Jedan od osnovnih ciljeva radnog zakonodavstva jest pronalazak pravog omjera zaštite prava radnika i obveza poslodavaca. U tom smislu sva odgovornost nije samo na zakonodavcu, nego posebnu važnost imaju i sudovi, čije odluke imaju dalekosežne ne samo pravne, već i ekonomske i socijalne učinke.

U području kolektivnog viška radnika, europski zakonodavac propisuje pragove minimalne zaštite u Direktivi 98/59, te ostavlja mogućnost državama članicama da povoljnije za radnika urede predmetno pitanje. Prilikom implementacije dvije opcije koje Direktiva 98/59 nudi, države članice moraju posebno voditi računa o značenju pojma "pogon" na koji se direktiva referira, te ovisno o čijem tumačenju je poslodavac dužan prilikom izračuna broja viška radnika voditi računa, o pojedinom

${ }^{84}$ Vidi primjerice presudu Županijskog suda u Zagrebu u predmetu Gžr-389/07-2 od 22. IV. 2008. u kojem sporu je radničko vijeće postavilo tužbeni zahtjev za utvrđene nedopuštenim i uklanjanje videonadzora koji je poslodavac stavio bez prethodne suglasnosti radničkog vijeća. U odnosu na pitanje aktivne legitimacije radničkog vijeća, Županijski sud u Zagrebu široko tumači ovlasti radničkog vijeća kod obveze savjetovanja te navodi da je „Pravilno sud prvog stupnja utvrdio da je konkretno pravno pitanje dopustivosti video nadzora od važnosti za položaj radnika u smislu čl. 145 st. 1 Zakona o radu ("Narodne novine", br. 38/95, 54/95, 64/95), a tužitelj-Zaposleničko vijeće je upravo zakonom ovlašteno tijelo štititi i promicati interese radnika (čl. 145 st. 1 ZR-a). Zato neosnovano žalba dovodi u pitanje aktivnu legitimaciju tužitelja."

85 Prekršajni zakon, Narodne novine, 110/2015. 
pogonu ili o svim pogonima kod poslodavca. Analizom recentne presude u predmetu Woolworths, autor iznosi svoj kritički osvrt smatrajući da je Sud EU u tom predmetu prilikom tumačenja pojma "pogon" prvenstveno vodio računa o obvezama i troškovima poslodavaca, te na taj način pružio niži stupanj zaštite radnicima.

Hrvatski Zakon o radu u svojoj definiciji kolektivnog viška radnika ne sadrži pojam "pogon", te je time osigurana šira zaštita radnika, odnosno obveza da se višak radnika utvrđuje na razini cijelog poslodavca. Međutim, postavlja se pitanje je li takvo rješenje rezultat prave namjere hrvatskog zakonodavca da primjeni povoljnije pravo za radnike, te je li ono u potpunosti usklađeno sa zahtjevima iz Direktive 98/59. Naime, ako je Republika Hrvatska zaista željela primijeniti povoljnije uređenje radničkih prava na način na koji to Direktiva 98/59 omogućuje, tada bi definicija kolektivnog otkazivanja trebala biti usklađena s Direktivom 98/59. Međutim, do drugačijeg zaključka bi se moglo doći ukoliko je prava namjera bila potpuno usklađivanje samo s drugom opcijom, koju Direktiva 98/59 nudi i koja se referira na pojam "pogon", ali je zbog određenog previda ili netočnog prijevoda izostala. Za očekivati je da će konačnu ocjenu usklađenosti dati hrvatski sudovi primjenom metode o posrednom ili interpretativnom učinku europskog prava ili postavljanjem prethodnog pitanja Sudu EU. Osim toga, hrvatski zakonodavac uvijek ima priliku ukloniti sve nedoumice jasnijim postavljenjem definicije kolektivnog viška radnika. U svakom slučaju, bez obzira na inače načelno suprotstavljene interese radnika i poslodavaca, čini se da bi takvo razjašnjenje ovog pitanja bilo u obostranom interesu.

\section{Literatura}

\section{Članci i knjige}

1. Antić, T. (2015.)., „Vjerodostojno tumačenje zakona“, Zbornik Pravnog fakulteta Sveučilišta u Rijeci, 36 (1), 619-644.

2. Benecke M., Groß N. (2015.). „Der europäische Betriebsbegriff“, EuZW, 15.

3. Bernard, C. (2012.). EU Employment Law, fourth edition, Oxford.

4. Craig, P., De Búrca, G. (2015.). EU Law, Text, Cases and Materials, Sixth Edition, Oxford.

5. Čavkar, D., Frntić, D. F., Gović Penić, I., Gruban, M., Milković, D., Novaković, N., Rožman, K., (2014.). Detaljni komentar novog Zakona o radu, Zagreb.

6. Čavrak, D., Gruban, M. (2012.). „Stranačka sposobnost radničkog vijeća, pravo radničkog vijeća na odabir punomoćnika i trošak zastupanja radničkog vijeća po punomoćniku odvjetniku“, Radno pravo, 5, 17.

7. Ćapeta, T, Rodin, S. (2009.). Osnove prava Europske unije, Zagreb.

8. Ćapeta, T. (2003.). „Odgovornost države za štetu u pravu Europske zajednice“, Zbornik Pravnog fakulteta u Zagrebu, 53, 3-4.

9. Gović Penić, I. (2014.). „Kolektivni višak radnika“, Pravo i porezi, 11, 5. 
Dora Gaži Kovačević: Definicija kolektivnog viška radnika u europskom i hrvatskom radnom... Zbornik radova Pravnog fakulteta u Splitu, god. 54, 3/2017., str. 659.- 682.

10. Greiner S., Hennecken M., (2015.). „Der Betriebsbegriff im Sinne der Massenentlassungsrichtlinie“, GPR, 6 .

11. MaschmannF.(2015.).,WasisteinBetriebimSinnederMassentlasssungsrichtlinie“, EuZA, 488.

12. Rodin, S. (2005.). „Demokratsko-pluralistička kritika instituta tzv. vjerodostojnog tumačenja“, Informator, 53, 1-4.

13. Zlatović, D., Malenica, I. (2016.). Novo hrvatsko radno pravo, Zagreb.

\section{Pravni propisi i sudska praksa}

14. Ustav Republike Hrvatske, Narodne novine 85/10.

15. Direktiva Vijeća 75/129/EEZ o usklađivanju zakonodavstava država članica u odnosu na kolektivno otkazivanje (1975.). SL L 48.

16. Direktiva Vijeća 98/59 o usklađivanju zakonodavstava država članica u odnosu na kolektivno otkazivanje (1998.). SL L 225, 16-21; pročišćeni tekst dostupan na http://eurlex.europa.eu/legal-content/HR/TXT/HTML/?uri=CELEX:01998L0059-20151009\&qid $=1468669417291 \&$ from $=$ HR

17. Konačni prijedlog zakona o izmjenama i dopunama Zakona o radu, PZE. 461 od 22. listopada 2009.

18. Konačni prijedlog Zakona o izmjenama i dopunama Zakona o radu, PZE 641, drugo čitanje od 12. lipnja 2003.

19. Mišljenje nezavisnog odvjetnika Nilsa Wahla u predmetima C-182/13, C-392/13 i C-80/14, dostupno na http://eur-lex.europa.eu/legal-content/HR/TXT/HTML/?uri=CEL EX:62013CC0182\&qid=1473669330641\&from $=$ HR

20. Odluka Ustavnog suda Hrvatske br. U-III-4883/2015 od 25. svibnja 2016.

21. Poslovnik Hrvatskog sabora, Narodne novine 81/2013.

22. Predmet Andrés Rabal Cañas protiv Nexea Gestión Documental SA, Fondo de Garantía Salarial, C-392/13.

23. Predmet Arie Botzen and others v Rotterdamsche Droogdok Maatschappij BV., C-186/83 (1985.) ECR I-00519.

24. Predmet Athinaïki Chartopoiïa AE protiv L. Panagiotidis i dr, C-270/05 (2007.) ECR I-01499.

25. Predmet Foster i ostali v. British Gas, C-188/89 (1990.) ECR I-3313.

26. Predmet M.H. Marshall v. Southampton and South-West Hampshire Area Health Authority, C-152/84 (1886.) ECR 723.

27. Predmet Marleasing SA protiv La Comercial Internacional de Alimentacion SA, C-106/89 (1990.) ECR I-04135.

28. Predmet Rockfon A/S v Specialarbejderforbundet i Danmark, C-449/93 (1995.) ECR I-04291.

29. Predmet Union of Shop, Distributive and Allied Workers (USDAW), B. Wilson protiv WW Realisation 1 Ltd, u stečaju, Ethel Austin Ltd i Secretary of State for Business, Innovation and Skills, C-80/14. 
30. Predmet United Kingdom of Great Britain and Northern Ireland v Council of the European Union, C-84/94 (1997.) ECR I-03519.

31. Predmet Valerie Lyttle, Sarah Louise Halliday, Clara Lyttle, Tanya McGerty protiv Bluebird UK Bidco 2 Ltd, C-182/13.

32. Prekršajni zakon, Narodne novine, 110/2015.

33. Presuda Vrhovnog suda, VSRH Gž 12/09-2 od 18. ožujka 2009.

34. Presuda Vrhovnog suda, VSRH Gž 42/1999-2 od 10. svibnja 2000.

35. Presuda Vrhovnog suda, VSRH Revr-217/02-2 od 8. svibnja 2002.

36. Presuda Vrhovnog suda, VSRH Revr-721/05-2 od 25. srpnja 2007.

37. Presuda Županijskog suda u Zagrebu, Gžr-389/07-2 od 22.04.2008.

38. Rješenje Vrhovnog suda, Revr-943/14-4 od 11. veljače 2015.

39. Rješenje Županijskog suda u Zagrebu, Gžr-2174/13-2 od 11. ožujka 2014.

40. Ugovor o funkcioniranju Europske unije (2010.) C2010/83/01, pročišćeni tekst dostupan na http://www.mvep.hr/custompages/static/hrv/files/pregovori/111221lisabonski-prociscena.pdf

41. Zakon o izmjenama i dopunama Zakona o radu, Narodne novine, 114/2013.

42. Zakon o parničnom postupku, Narodne novine, 53/1991, 91/1992, 112/1999, 129/2000, 88/2001, 117/2003, 88/2005, 2/2007, 96/2008, 84/2008, 123/2008, 57/2011, $25 / 2013,89 / 2014$

43. Zakon o parničnom postupku, Službeni list SFRJ 4/1977, 36/1977, 36/1980, 6/1980, 69/1982, 43/1982, 58/1984, 74/1987, 57/1989, 20/1990, 27/1990, 35/1991.

44. Zakon o radu, Narodne novine, 149/09.

45. Zakon o radu, Narodne novine, 93/2014.

\section{Internetski izvori}

46. Countouris, N., Koukiadaki, Aristea. The Purpose of European Labour Law: Floor Of Rights - Or Ceiling?, dostupno na https:/www.socialeurope.eu/2016/06/ purpose-european-labour-law-floor-rights-ceiling/

47. Godišnje Izvješće o radu Hrvatskog zavoda za zapošljavanje (HZZZ) za 2014. godinu, dostupno na http://www.hzz.hr/UserDocsImages/Izvjesce_o_radu_HZZ_2014. pdf

48. Godišnji Izvještaj Europske komisije za 2015. Monitoring the Application of European Union Law, dostupan na http://ec.europa.eu/atwork/applying-eu-law/docs/ annual_report_33/country_sheet_hr_en.pdf

49. Komunikacija Komisije Europskom parlamentu, Vijeću, Europskom gospodarskom i socijalnom odboru i Odboru regija, o pokretanju javne rasprave o europskom stupu socijalnih prava, dostupno na http://ec.europa.eu/transparency/regdoc/ rep/1/2016/HR/1-2016-127-HR-F1-1.PDF

50. Reade, D., International Corporate Rescue: Woolworths and the ECJ case Review, dostupno na http://www.littletonchambers.com/international-corporate-rescuewoolworths-and-the-ecj-case-review-896/ 


\section{DEFINITION OF COLLECTIVE REDUNDANCY UNDER EU AND CROATIAN LABOR LEGISLATION}

The author analyses the definition of collective redundancy under EU and Croatian labor legislation, with a particular emphasis on the method of calculation of redundant workers. The paper examines the situations in which the collective redundancy procedure will be triggered, and if at least 20 workers are being made redundant over a period of 90 days in a single employer's establishment or in aggregate across all its sites.

The Council's Directive 98/59/EC on collective redundancies sets out relevant thresholds that should be implemented in the national legislation of the Member States and also provides the option for Member States to provide more employee-friendly redundancy rules. However, Directive 98/59/ EC provides no definition of the key term "establishment" that was thus interpreted by the Court of Justice of the European Union in a number of cases. The most recent clarification on when the collective redundancy procedure applies was given in the Woolworths case that is the subject of the author's special commentary. Since the relevant provisions of the Croatian Labor Act currently in force make no reference to the term "establishment", the correct implementation of the Directive 98/59/EC into Croatian law is brought into question. The author also examines the consequences of potential non-compliance with EU law.

Key terms: Collective redundancy, establishment, redundant workers 